\title{
THE
}

\section{Tick saliva is a potent inhibitor of endothelial cell proliferation and angiogenesis}

Ivo M.B. Francischetti

Thomas N. Mather

University of Rhode Island, tmather@uri.edu

José M.C. Ribeiro

Follow this and additional works at: https://digitalcommons.uri.edu/pls_facpubs

This is a pre-publication author manuscript of the final, published article.

Terms of Use

All rights reserved under copyright.

\section{Citation/Publisher Attribution}

Francischetti, I. M.B., Mather, T. N., \& Ribeiro, J. M.C. (2005). Tick saliva is a potent inhibitor of endothelial cell proliferation and angiogenesis. Thromb. Haemost., 94(1), 167-174. doi: 10.1160/TH04-09-0566

Available at: http://dx.doi.org/10.1160/TH04-09-0566

This Article is brought to you for free and open access by the Plant Sciences and Entomology at DigitalCommons@URI. It has been accepted for inclusion in Plant Sciences and Entomology Faculty Publications by an authorized administrator of DigitalCommons@URI. For more information, please contact digitalcommons@etal.uri.edu. 


\title{
Tick saliva is a potent inhibitor of endothelial cell proliferation and angiogenesis
}

\author{
Ivo M. B. Francischetti ${ }^{1,}{ }^{*}$, Thomas N. Mather ${ }^{2}$, and José M. C. Ribeiro ${ }^{1}$ \\ 1 Vector Biology Section, Laboratory of Malaria and Vector Research, National Institute of Allergy \\ and Infectious Diseases, National Institutes of Health, Rockville, MD 20892-8132, USA \\ ${ }^{2}$ Center for Vector-borne Disease, University of Rhode Island, Kingston, RI 02881-0804, USA
}

\section{Abstract}

\begin{abstract}
We report for the first time that saliva of the hard tick and Lyme disease vector, Ixodes scapularis, is a potent inhibitor of angiogenesis. Saliva ( $\leq 1: 500$ dilutions) or salivary gland (0.1-0.5 pairs/assay) dose-dependently inhibits microvascular endothelial cell (MVEC) proliferation. Inhibition was also detected with the saliva of the cattle tick Boophilus microplus but not with the salivary gland of Anopheles gambiae, An. stephensiae, Lutzomyia longipalpis, Phlebotomus papatasi, Aedes aegypti, Culex quinquefasciatus, and Cimex lectularius. Inhibition of MVEC proliferation by I. scapularis saliva was accompanied by a change in cell shape (shrinkage of the cytoplasm with loss of cell-cell interactions) and apoptosis which was estimated by expression of phosphatidylserine using the Apopercentage dye, and by a typical pattern of chromatin margination, condensation, and fragmentation as revealed by nuclear staining with Hoechst 33258. The effect of saliva appears to be mediated by endothelial cell $\alpha 5 \beta 1$ integrin, because monoclonal antibodies against this but not $\alpha v \beta 3, \alpha v \beta 5, \alpha 9 \beta 1$, or $\alpha 2 \beta 1$ integrins remarkably block its effect. In addition, SDS/PAGE shows that saliva specifically degrades purified $\alpha 5 \beta 1$ but not $\alpha v \beta 5$ or $\alpha v \beta 3$ integrins. Incubation of saliva with EDTA and 1,10-phenanthroline, but not phenylmethylsulfonyl fluoride (PMSF), inhibits salivadependent degradation of purified $\alpha 5 \beta 1$ integrin, suggesting that a metalloprotease is responsible for the activity. Finally, saliva at $\leq 1: 1,000$ dilution blocks sprouting formation from chick embryo aorta implanted in Matrigel, an in vitro model of angiogenesis. These findings introduce the concept that tick saliva is a negative modulator of angiogenesis-dependent wound healing and tissue repair, therefore allowing ticks to feed for days. Inhibition of angiogenesis was hitherto an unidentified biologic property of the saliva of any blood-sucking arthropod studied so far. Its presence in tick saliva may be regarded as an additional source of angiogenesis inhibitors with potential applications for the study of both vector and vascular biology.
\end{abstract}

\begin{abstract}
Angiogenesis, the formation of new blood vessels, occurs as a result of the growth of capillaries by vascular sprouting from preexisting vessels (1). Upon growth stimulation, quiescent endothelial cells can enter into the cell cycle, migrate, degrade the underlying basement membrane, and form a lumen. Angiogenesis is required for a variety of physiologic processes such as embryonic development and wound healing. Wound healing involves a dynamic and changing process that has been conveniently divided into three phases-inflammatory, proliferative, and remodeling (2). This process is continuous; the phases overlap, and different mechanisms occurring at different times trigger the release of chemical signals that modulate orderly migration, proliferation, and differentiation of cells and the synthesis and degradation of extracellular matrix (ECM) proteins (2). Of note, angiogenesis is generally considered to be
\end{abstract}

*Corresponding author. Mailing address: Vector Biology Section, LMVR, NIAID, NIH, 12735 Twinbrook Parkway (Twinbrook III), Room 2E-28, Rockville, MD 20892-8132. Tel: 301-402-2748. Fax: 301-480-2571. ifrancischetti@ niaid.nih.gov. 
a phenomenon that occurs during the proliferative phase of wound healing $(3,4)$. This phase is critical for the formation of granulation tissue, a hallmark of wound healing characterized by proliferation of endothelial cells, fibroblast accumulation, and collagen synthesis. Accordingly, granulation tissue provides nutrition, oxygen, and physical support for the tissue in repair (3, 4). Angiogenesis is also involved in the pathogenesis of some diseases, including cancer (3, 4).

The tick vector of Lyme disease, Ixodes scapularis, is an ectoparasite that feeds for several days with its mouthpart embedded in the vertebrate host (5). To counteract the acute host response (acute inflammation) that occurs minutes after injury, tick saliva contains a number of molecules with antiinflammatory and antihemostatic properties (6-7); however, ticks feed on blood for long periods of time (days) in contrast to mosquitoes, which take a meal in minutes and are considered fast feeders (5). Accordingly, we have hypothesized that late host responses to injury, such as endothelial cell-dependent wound healing $(3,4)$ are negatively modulated by tick saliva. We report here that I. scapularis saliva is a potent inhibitor of angiogenesis.

\section{MATERIALS AND METHODS}

\section{Reagents}

All water used was of $18 \mathrm{M} \Omega$ quality produced by a MilliQ apparatus (Millipore, Bedford, MA). Organic compounds, Hoescht 33258, propidium iodide (PI), phenylmethylsulfonyl fluoride (PMSF), pilocarpine, polymixin B, and 1,10-phenantroline and formaldehyde were obtained from Sigma Chemical (St. Louis, MO) or as stated. Tris-buffered saline (TBS) was from BioSource International (Rockville, MD). Human dermal microvascular endothelial cells (MVEC), human umbilical endothelial cells (HUVEC), endothelial cell basal medium-2 (EBM-2), fetal bovine serum, Single Quotes, Reagent Pack and Penstrep (100x) were purchased from Cambrex (Walkersville, MD). Purified monoclonal antibodies (mAb) antiintegrin $\alpha 5 \beta 1$ (HA6), anti- $\alpha \beta \beta 3$ (LM609), anti- $\alpha v \beta 5$ (P1F6), and anti- $\alpha 9 \beta 1$ (Y9A2), in addition to anti- $\alpha 2 \beta 1$ (BHA2.1), anti- $\alpha 3 \beta 1$ (MK1D2), anti- $\beta 1$ (P4G11), anti- $\beta 2$ (P4H9), anti- $\alpha 1$ (FB12), anti- $\alpha 2$ (P1E6), anti- $\alpha 3$ (P1B5), anti- $\alpha 4$ (P1H4), anti- $\alpha 5$ (P1D6), anti- $\alpha 6$ (NKI-GoH3), anti$\alpha v$ (P3G8), and ascites anti- $\alpha 5 \beta 1$ (JBS4) were from Chemicon International (Temecula, CA). Purified $\mathrm{mAb}$ anti- $\alpha \mathrm{v} \beta 3$ (23C6) and $\alpha \mathrm{v} \beta 5$ (P1F76) were from Santa Cruz Biotechnology, Inc. (Santa Cruz, CA). Matrigel was acquired from BD Bioscience (San José, CA). Twelve-dayold chick embryo was from CBT Farms (Chestertown, MD). Pre-cast gels, See Blue molecular weight markers, and LDS buffer were from Invitrogen (Carlsbad, CA).

\section{Ticks, tick saliva, and other blood-sucking salivary glands}

Tick saliva was obtained by inducing partially engorged adult female I. scapularis to salivate (3-4 days post attachment to a rabbit) into capillary tubes using the modified pilocarpine induction method (8). Other salivary glands were obtained from mosquitoes and sandflies kept in the insectary of the Laboratory of Malaria and Vector Research (LMVR, NIH) under the direction of Mr. André Laughinhouse.

\section{Human dermal MVEC and HUVEC culture}

MVEC and HUVEC were purchased from Clonetics (San Diego, CA) and grown at $37^{\circ} \mathrm{C}, 5 \%$ CO2 in T-25 flasks in the presence of EBM-2 Plus: EBM-2 containing 2\% fetal bovine serum, and Single Quotes (h-fibroblast growth factor-B, vascular endothelial growth factor, $\mathrm{R}^{3}$-insulin growth factor, ascorbic acid, h-epidermal growth factor, hydrocortisone plus gentamycin and amphotericin B). Trypsinization was performed using Reagent Pack (trypsin-EDTA, trypsin neutralization solution, and HBSS) according to the manufacturer instructions (Cambrex, MD). 


\section{Proliferation assay kit}

Cell proliferation assays were performed using the CellTiter 96 aqueous non-radioactive cell proliferation assay kit (Promega, Madison, WI). This assay uses MTS solution containing 3(4,5-dimethylthiazol-2-yl)5-(3-carboxymethoxyphenyl)-2-(4-sulfophenyl)-2H-tetrazolium) and phenazine methosulphate. MTS is bioreduced by cells into a formazan product soluble in tissue culture medium.

\section{Cell proliferation assays}

This was performed as described (9). In brief, after trypsinization, MVEC were seeded at 3.2 $\times 10^{3} /$ well in 96-well polystyrene tissue culture-treated plates (Corning Inc., Corning, NY) and grown for 1 day in the presence of EBM-2 Plus. Then, EBM-2 Plus was replaced by $200 \mu \mathrm{L}$ of fresh EBM-2 Plus, and saliva was added $(0-10 \mu \mathrm{L})$. After 3 days of incubation of MVEC (in $200 \mu \mathrm{l}$ of EBM-2 Plus) with saliva, $40 \mu \mathrm{l}$ of MTS solution was added to the wells. After 4 $\mathrm{h}$ at $37^{\circ} \mathrm{C}$, absorbance at $490 \mathrm{~nm}$ was measured spectrophotometrically using a Versamax microplate reader equipped with the appropriate software (Molecular Devices, San Diego, CA). Results were estimated as percent inhibition, considering $100 \%$ the MVEC growth in the presence of EBM-2 Plus and 0\% the growth of MVEC in the presence of supramaximal amounts of saliva that completely prevented proliferation. LDH release was estimated using the cytotoxicity detection kit (Roche Diagnostics, Mannheim, Germany).

\section{Saliva-induced change in MVEC shape and the effects of anti-integrin mAb}

In 96-well plates, MVEC at 90\% confluency in EBM-2 Plus (200 $\mu$ l) were incubated with saliva $(5 \mu \mathrm{l})$ for different time points. In some experiments, MVEC were incubated for $1 \mathrm{~h}$ with $\mathrm{mAb}$ anti-integrin $(25 \mu \mathrm{g} / \mathrm{ml})$ followed by addition of saliva as described above. Change in cell shape morphology was observed using a Axiovert 200 (HAL 100) inverted fluorescence microscope (Carl Zeiss, Jena, Germany) using an objective of 10x. Pictures were taken with an AxioCam digital camera (camera mode in black and white; $1300 \times 1030$ standard mono) coupled to the microscope. Image was handled using AxioVision 4.1 software (Carl Zeiss).

\section{Degradation of integrins}

Purified integrins ( $3 \mu \mathrm{g}$ in $15 \mu \mathrm{l}$ ) were diluted to $30 \mu \mathrm{l}$ in EBM-2 (containing $1.5 \mathrm{mM} \mathrm{Ca}^{2+}$, and $0.02 \% \mathrm{BSA}$ ) followed by addition of $5 \mu \mathrm{l}$ of saliva. In some experiments, Eppendorfs tubes containing $15 \mu \mathrm{l}$ of EBM-2 and $5 \mu \mathrm{l}$ of saliva were incubated for 30-min with $1.5 \mu \mathrm{l}$ EDTA (20 mM, final concentration), $0.3 \mu \mathrm{LMSO}(1 \% \mathrm{v} / \mathrm{v})$, PMSF $(2.5 \mathrm{mM})$ or 1,10-phenantroline $(2.5 \mathrm{mM})$. PMSF and 1,10-phenatroline were diluted at $250 \mathrm{mM}$ stock solution in DMSO $(100 \%, \mathrm{v} / \mathrm{v})$. Then, purified integrin $\alpha 5 \beta 1(15 \mu \mathrm{l})$ was added and incubation was performed in a thermocycler overnight at $37^{\circ} \mathrm{C}$. To stop the reactions, $15 \mu \mathrm{l}$ of LDS buffer (Invitrogen, Carlsbad) containing SDS was added to the samples followed by heating at $80^{\circ} \mathrm{C}$ for $10 \mathrm{~min}$. Samples were loaded in $4 \%$ to $12 \%$ NU-PAGE pre-cast gels with MES buffer (Invitrogen, CA). Gels were stained in $0.2 \%$ Coomassie blue, $45 \%$ methanol, $15 \%$ acetic acid, and destained in $45 \%$ methanol, $15 \%$ acetic acid.

\section{Membrane changes using Apopercetage dye}

This was performed as described (10). In brief, MVEC were grown to 90\% confluency on 96microwell plates containing EBM-2 Plus. In the day of the experiment, $2.5 \mu 1$ saliva was added to the wells in the presence of EBM-2 Plus $(100 \mu \mathrm{l})$ and incubated for $3.5 \mathrm{~h}$ at $37^{\circ} \mathrm{C}, 5 \%$ $\mathrm{CO}_{2}$. Then, $100 \mu \mathrm{l}$ of pre-warmed EBM-2 Plus containing $5 \mu \mathrm{l}$ Apopercentage dye (Biocolor, Northern Ireland) was added to the wells for 30 minutes. Wells were washed 3 times with EBM-2, and cells were observed in an inverted microscope coupled to a digital camera (Carl Zeiss Axiovert 200). Apopercentage dye allows measurement of the expression of phosphatidylserine on the outside surface of the cell membrane, which is therefore similar to 
what is measured by traditional annexin-V labelling. The transfer of phosphatidylserine to the outside surface of the cell membrane permits the unidirectional transport of the Apopercentage dye inside the cell, where it is retained and accumulates as a purple-red dye in apoptotic cells which can be observed in a conventional inverted non-fluorescence microscope as described in (10) and in the User's manual (Biocolor).

\section{Nuclear changes of apoptosis using Hoechst $\mathbf{3 3 2 5 8}$ staining and fluorescence microscopy}

This was performed as reported (11). Briefly, MVEC were grown to $90 \%$ confluency on glass coverslips placed in a 24-microwell plates containing EBM-2 Plus. In the day of the experiment, saliva $(5 \mu \mathrm{l})$ was added to the coverslips in the presence of EBM-2 Plus (200 $\mu \mathrm{l})$ and incubated for $6 \mathrm{~h}$ at $37^{\circ} \mathrm{C}, 5 \% \mathrm{CO}_{2}$. Cells were carefully washed three times with EBM-2, fixed with $3.7 \%$ formaldehyde (in TBS buffer, $\mathrm{pH}$ 7.4) for $15 \mathrm{~min}$, washed with TBS and then stained for $30 \mathrm{~min}$ with $25 \mu \mathrm{M}$ Hoechst 33258 (in TBS). Coverslips were washed, removed from the wells and briefly rinsed in distilled water. Then, precision wipes (Kimberly-Clark, United Kingdom) were used to dry the excess liquid by touching the edge of the coverslips. Coverslips were inverted and placed in a glass slide containing $9 \mu \mathrm{l}$ of Vectashield mounting medium for fluorescence (Vector Laboratories; Burlingame, CA). In some assays, cells were treated with saliva as described above but without fixation and stained with Hoechst 33258 and propidium iodide (PI, $2.5 \mu \mathrm{g} / \mathrm{ml}$ ). Nuclear morphologic changes were examined using an inverted fluorescence microscopy (Carl Zeiss Axiovert 200, HAL 100) equipped with DAPI and rhodamine filters for Hoechst 33528 and PI staining, respectively.

\section{Aortic ring assay}

Twelve-day-old chick eggs were cracked and the embryo removed from its surroundings. The chick ventral was arranged side up and the head removed. Tweezers were used to lift the tissue above the breastbone, and scissors were used to trim the tissue above the thoracic cavity to exposure the heart and the aortic arch. The heart and aortic arch were carefully removed and placed in PBS plus 1\% Penstrep. Under the dissection microscope, excess tissue was removed, and the clean arches were cut into $\sim 0.8-\mathrm{mm}$ pieces as described $(25,33)$. Because the ends of the aortas were held by forceps during the cleaning and cutting and may have been damaged, they were discarded. Plates (96-well) were coated with $3 \mu 1$ of Matrigel; after gelling, rings were placed into the wells and sealed in place with a $2 \times 10 \mu \mathrm{l}$ overlay of Matrigel. Then, 100 $\mu \mathrm{lEBM}-2$ with $1 \%$ Pentrep was added, followed by addition of saliva or salivary gland (up to $10 \mu \mathrm{l})$. Sprouting was observed for 3 days, and pictures were taken as described above using a digital camera coupled to an inverted microscope. Each data point was assayed in triplicate, and each experiment was repeated at least three times. A blinded observer scored outgrowth by comparing responses with media alone (positive control) to that observed with saliva.

Results were scored as follows: ++++ (or 100\%), sprouting comparable to positive control; + $++($ or $75 \%$ ), significant sprouting but lower than positive control; ++ (or 25\%), significant sprouting above background levels; + (or 10\%), low levels of sprouting; and $\pm(<10 \%)$, some sprouting above negative control levels.

\section{RESULTS}

\section{I. scapularis saliva inhibits proliferation of human dermal MVEC}

Fig. 1A shows that saliva of the tick I. scapularis inhibits proliferation of MVEC in the presence of EBM-2 Plus in a concentration-dependent manner, with an $\mathrm{IC}_{50}$ of $\sim 0.5 \mu \mathrm{l}$ of saliva per assay (200 $\mu$ l) or $\sim 1: 500$ dilution. Fig. 1B shows that $I$. scapularis salivary glands were equally potent with $\mathrm{IC}_{50}$ of $\sim 0.2$ pairs/assay ( $\mathrm{n}=3$; not shown). Similar results were obtained using human umbilical vein endothelial cells (HUVEC) incubated with $I$. scapularis saliva or salivary gland, including the $\mathrm{IC}_{50}$ values in the same range ( $\mathrm{n}=5$; not shown). Strong inhibition of MVEC proliferation was also detected with the salivary glands of the tick Boophilus 
microplus ( 1 pair/assay; not shown) whereas partial blockade ( 35\%) was attained with the salivary gland of Rhodnius prolixus ( 1 pair/assay, not shown). On the other hand, inhibiton was not detected when MVEC was incubated with the salivary gland of Anopheles gambiae, An. stephensi, Culex quinquefasciatus, Cimex lectularius, Aedes aegypti, Lutzomyia longipalpis, or Phlebotomus papatasi (up to 2.5 pairs/assays; $n=3$ )(Fig. 1B).

As a control, we demonstrate that the effects of saliva are not due to pilocarpine used to induce salivation (8) and known to reach high concentrations in this secretion (14). Accordingly, exogenously added pilocarpine (up to $2.5 \mathrm{mM}$ ) did not affect MVEC proliferation (not shown). Also, the effects of saliva are not due to contaminating LPS, known to affect MVEC. In fact, dose-dependent inhibition of MVEC proliferation by saliva was the same regardless of the presence of polymixin B $(10 \mu \mathrm{g} / \mathrm{ml})$, a reagent that binds LPS (not shown; $\mathrm{n}=3$ ).

\section{I. scapularis saliva induces a dramatic change in the morphology of MVEC}

Fig. 2A shows typical $80 \%$ to $90 \%$ confluent MVEC in culture. Exposure of MVEC to tick saliva led cells to retract, round up, and detach, forming gaps among cells and multicellular aggregates. Change in shape and refringency started 15-30 min after saliva addition (Fig. 2B, 2C), was evident after 1-2 h (Fig. 2D, 2E), and was remarkable at $6 \mathrm{~h}$ (Fig. 2F). The change was characterized by shrinkage of the cytoplasm and apparent loss of cell-cell interactions $(\mathrm{n}=10)$.

\section{Inhibition of angiogenesis by $I$. scapularis saliva is specifically prevented by anti- $\alpha 5 \beta 1 \mathrm{mAb}$}

Fig. 3, A and B, show, respectively, the effects of buffer (negative control) and saliva (positive control) in MVEC shape after a 6-h incubation. Incubation of MVEC with mAb against anti$\alpha v \beta 3$ (Fig. 3C), anti- $\alpha v \beta 5$ (Fig. 3D), and anti- $\alpha 9 \beta 1$ (Fig. 3E) did not interfere with the effects of saliva. In contrast, Fig. 3F shows that anti- $\alpha 5 \beta 1 \mathrm{mAb}$ reduced the change in cell shape promoted by saliva. Similar results were obtained with anti- $\alpha 5 \beta 1$ from ascites (JBS4)(not shown). Other anti-integrin mAb including anti- $\alpha 2 \beta 1$, anti- $\alpha 3 \beta 1$, anti- $\beta 1$, anti- $\beta 2$, anti- $\alpha 1$, anti$\alpha 2$, anti- $\alpha 3$, anti- $\alpha 4$, anti- $\alpha 5$, anti- $\alpha 6$, and anti- $\alpha$ v were consistently without effects (pictures not shown).

\section{I. scapularis saliva degrades integrin $\alpha 5 \beta 1$ and $\alpha 1 \beta 1$}

To further explore the mechanism of action of saliva, different integrins were incubated with saliva in vitro in the presence of EBM-2 $\left(1.5 \mathrm{mM} \mathrm{Ca}^{2+}\right)$ followed by analysis of enzyme activity by SDS/PAGE. Fig. 4A shows that saliva did not degrade integrins $\alpha v \beta 3$ and $\alpha v \beta 5$. In contrast, Figure 4B shows that the proteolytic activity of saliva was able to degrade both $\alpha$ and $\beta$ subunits of integrin $\alpha 5 \beta 1$ and $\alpha 1 \beta 1$. The proteolytic effect appears to be mediated by a metalloprotease since EDTA (20 mM), or 1,10-phenatroline (2.5 mM), but not PMSF (2.5 mM), attenuate degradation of integrin $\alpha 5 \beta 1$ by saliva (Fig. 4C).

\section{I. scapularis saliva induces apoptosis of MVEC}

Based on the experimental results showing that saliva inhibits MVEC proliferation and the change of cell shape observed under the microscope, it was plausible to suggest that apoptosis was the mechanism mediating saliva-induced cell death. Apoptosis, or programmed cell death, plays a fundamental role in many normal biologic processes (15). Apoptotic cells undergo an orchestrated cascade of events characterized by distinct morphologic and biochemical changes that take place on the cell surface, in the cytoplasm, and in the nucleus $(9,15)$. In an attempt to detect apoptosis, we have used the Apopercentage dye that allows measurement of the expression of phosphatidylserine on the outside surface of the cell membrane $(10,11)$. Therefore this method is similar to what is measured by traditional annexin-V labeling that is known as one of the most specific markers of apoptosis (15). Fig. 5A shows that MVEC 
incubated with saline were not stained by the Apopercentage dye confirming that these cells are viable and non-apoptotic. In contrast, Figure 5B shows that the MVEC incubated with saliva changed their shape and many of them stained in red-purple by the Apopercentage dye (arrows), which is indicative of apoptosis.

A second assay was used to confirm apoptosis in these cells. Cells were incubated with saliva for 6 hours and then stained with Hoechst 33258, a membrane-permeable dye that is specific for nuclear DNA(see Methods). Nuclear changes are among the most sensitive markers of apoptosis $(11,15,16)$. Fig. 5C shows the nucleus of MVEC without treatment, which is characterized by a smooth and regular contour. Fig. 5D shows the nucleus of saliva-treated cells, presenting typical morphologic changes of apoptotic cells characterized by highly condensed, marginated, and fragmented chromatin $(9,11,15,17)$. In some experiments, MVEC treated with saliva but not fixed were incubated with propidium iodide (PI). PI specifically stains (red) the nucleus of cells that have lost membrane permeability due to necrosis but not to early apoptosis. Because incubation of saliva-treated MVEC with PI was not accompanied by red staining of the nucleus (not shown), we conclude that saliva at this concentration and incubation time induces programmed cell death that retains an intact plasma membrane (15).

\section{I. scapularis saliva inhibits chick aorta ring sprouting}

The sprouting of vessels from aortic ring explants was used next to determine whether the tick saliva inhibited in vitro angiogenesis. Chick aortic rings were placed in Matrigel and incubated with EBM-2 (100 $\mu \mathrm{l})$. Fig. 6A shows a typical sprouting without saliva, resulting in dense networks of sprouts. Fig. 6, B-D, shows the striking inhibitory effects of saliva that starts with $0.1 \mu \mathrm{l}$ (1:1000 dilution) and is complete with $1 \mu \mathrm{l}$. Fig. $6 \mathrm{E}$ shows a dose-response curve for inhibition of sprouting formation by saliva with $\mathrm{IC}_{50} \sim 0.3 \mu \mathrm{l} /$ assay or $\sim 1: 500$ dilution. Salivary glands homogenates inhibited sprouting formation at $\sim 0.2$ pairs/assay ( $\mathrm{n}=4$; not shown).

\section{Orderly phases of wound healing are affected by tick saliva}

Fig. 7 summarizes the events associated with wound healing, a characteristically dynamic and changing process in three phases: inflammatory (inflammation), proliferative (granulation tissue), and remodeling (wound contraction). Salivary molecules such as the coagulation inhibitors Ixolaris (7), Penthalaris (18), (SALP14) (19)—in addition to an anti-complement protein, ISAC (20), a salivary inhibitor of neutrophil function (6,21), and a bradykinindegrading kininase $(5,22)$ - work in concert to effectively block the acute phase of inflammation. On the other hand, later stages of inflammation, during which endothelial celldependent granulation tissue formation takes place, appear to be counteracted by tick salivary components displaying anti-angiogenesis activities (see Discussion).

\section{DISCUSSION}

We describe for the first time the identification of two novel biologic activities in tick saliva: inhibition of endothelial cell proliferation and angiogenesis. Angiogenesis is conceptually defined as the formation of new blood vessels from existing ones and accordingly is essentially dependent on endothelial cells. Angiogenesis is important in a number of physiologic processes and is particularly relevant at late stages of wound healing. Wound healing is a critical step necessary for tissue repair and has been appropriately divided into three phases: inflammatory, proliferative, and remodeling (see Fig. 7). Of interest, angiogenesis occurs mostly during the proliferative phase, when formation of the so-called granulation tissue takes place. Granulation tissue - characterized by an intense proliferation of endothelial cells, fibroblast accumulation, and collagen synthesis - provides nutrition, oxygen, and physical support for growing tissue $(3,4)$. 
Because the proliferative phase of wound healing leading to granulation tissue formation starts 0.2-0.4 days after the onset of injury $(3,4)$, and ticks feed on blood for days, it is plausible that tick saliva contains molecules that specifically inhibit endothelial cell proliferation therefore impairing wound healing and tissue repair. In support to this contention, here we show that saliva and salivary gland of ticks, but not of mosquitoes or sand flies, are potent inhibitors of MVEC proliferation (Fig. 1A). At present however, it is uncertain which molecule is responsible for this property. Our assays using saliva suggest that an enzyme, most likely a fibrinogen(olytic) metalloprotease, accounts for the activity. This is supported by the finding that metalloprotease inhibitors EDTA or 1,10-phenanthroline (but not the serine protease inhibitor PMSF) inhibits degradation of integrin $\alpha 5 \beta 1$ by saliva, and also by the fact that anti$\alpha 5 \beta 1$ antibody attenuates the change in endothelial cells shape promoted by saliva. In addition, we have recently reported a full-length salivary gland cDNA (23) with substantial similarities to members of the snake venoms reprolysin family of metalloproteases (24). As reported here for tick saliva, some enzymes from this family are known to induce changes in endothelial cell morphology and to induce apoptosis by degrading integrin $\alpha 5 \beta 1(17,24-28)$. Proteolytic degradation of integrins may result in dysfunction of this receptor on the cell surface, an event that is closely associated with apoptosis $(16,29)$. In this regard, tick saliva induces apoptosis of MVEC as evidenced by membrane exposure of phosphatydilserine (Fig. 5B) and by a typical nuclear morphologic change characterized by condensation and fragmentation (Fig. 5D). As described for venom metalloproteases (17,24-28), apoptosis appears to occur prior to cell detachment although detachment-induced apoptosis (anoikis) can not be excluded. Finally, the finding that saliva induces apoptosis and not necrosis is consistent with the notion that tick saliva manipulates the host response toward a noninflammatory microenvironment at the site of attachment (5). Indeed, it is well known that cell death by apoptosis is not associated with the production of pro-inflammatory molecules (16).

The finding that integrin $\alpha 5 \beta 1$ is specifically the target of saliva is particularly important visa-vis the role of this integrin in inflammation and wound healing $(3,4)$. The $\alpha 5 \beta 1$ integrin is the major fibronectin receptor and is widely distributed (30). It is essential for cell growth and development and it plays an active role in anchorage-dependent cell survival (31). Of note, vascular injury is a stimulus for expression of $\alpha 5 \beta 1$ by vascular cells (32) and, among other effects, $\alpha 5 \beta 1$ integrin function in the regulation of SMC phenotype (32), migration and proliferation of SMC and endothelial cells (33), and leukocyte trafficking (34), in addition to controlling fibroblast function (35), and urokinase/urokinase receptor signaling (36).

Moreover, there are many reports showing that treatment with $\alpha 5 \beta 1$ antagonists reduced the vascular response after injury $(37,38)$. These studies, along with mechanistic data derived from cell culture experiments, provide compelling evidence that $\alpha 5 \beta 1$ integrin is involved in vascular repair processes $(3,4,31)$.

The inhibitory effects of saliva in angiogenesis appear not to be limited to a direct apoptotic effect in endothelial cells. Saliva has metalloprotease activity that degrades fibrin(ogen) and fibronectin (23); both molecules are known to function as a provisional matrix and to induce signals for endothelial cell proliferation, migration, and survival at different stages of angiogenesis and wound healing (38-42). Accordingly, it is not surprising that sprouting formation from chick embryo a-redundant process dependent on various pro-angiogenic factors, ECM proteins, and different cell types-is severely affected by saliva at remarkable diluted concentrations. Identification and expression of these molecules (e.g., metalloproteases) will help us to understand the mechanism by which saliva redundantly inhibits angiogenesis. Of interest, the tick metalloprotease contains disintegrin- and cysteine rich-like domains that are significantly smaller in size and in the number of cysteines (23) than those in venom P-III metalloproteases (24). It may be that these structural differences account for the specificity and mechanism of action of this enzyme (43). Finally, it should be pointed out that Kunitz-containing proteins (44) and calreticulin (45) - known to affect MVEC 
proliferation, also exist in tick saliva (22). We speculate that these and other salivary molecules, may contribute in a synergistic and redundant manner to the inhibition of angiogenesis observed herein. Salivary molecules targeting acute inflammation (5) and compounds with immunosuppressive properties $(46,47)$ may also play an indirect role in allowing ticks to feed for long periods of time.

Thus, saliva attenuates angiogenesis by at least two mechanisms: blockade of endothelial cell integrin function leading to apoptosis, and degradation of the provisional matrix. Inhibition of these events prevents formation of granulation tissue with inhibition of wound healing and tissue repair, therefore allowing ticks to successfully feed on blood for days. This is in contrast to mosquitoes and sand flies, two fast feeders species whose salivary glands appear not to affect endothelial cell proliferation. We also suggest that other cellular components of wound healing may be affected by tick saliva, including fibroblasts and macrophage function. Finally, we speculate that the ability of saliva to inhibit endothelial cell proliferation may also affect pathogen transmission by ticks $(49,50)$. Inhibition of angiogenesis was hitherto an unidentified biologic property of the saliva of any blood-sucking arthropods studied so far.

\section{Acknowledgments}

We are thankful to Drs. Thomas J. Kindt, Thomas E. Wellems, and Robert W. Gwadz (NIAID/NIH) for support. We thank Dr. Hynda K. Kleinman (NIDCR/NIH) for valuable discussions and advices concerning the chick embryo aorta sprouting assay. We are thankful to Dr. Carlos Termignoni (Federal University of Rio Grande de Sul, Brazil) for providing Boophilus microplus salivary gland and saliva. We are grateful to Brenda Rae Marshall for editorial assistance.

\section{References}

1. Folkman J, Shing T. Angiogenesis. J Biol Chem 1992;167:10931-10934. [PubMed: 1375931]

2. Risau W. Mechanism of angiogenesis. Nature 1997;386:671-674. [PubMed: 9109485]

3. Li J, Zhang YP, Kirsner RS. Angiogenesis and wound repair: angiogenic growth factors and the extracellular matrix. Microscopy Research and Technique 2003;60:107-114. [PubMed: 12500267]

4. Neal MS. Angiogenesis: is it the key to controlling the healing process? J Wound Care 2001;10:281287. [PubMed: 12964349]

5. Ribeiro JM, Francischetti IM. Role of arthropod saliva in blood feeding: sialome and post-sialome perspectives. Annu Rev Entomol 2003;48:73-88. [PubMed: 12194906]

6. Ribeiro JM, Makoul GT, Levine J, Robinson DR, Spielman A. Antihemostatic, antiinflammatory, and immunosuppressive properties of the saliva of a tick, Ixodes dammini. J Exp Med 1985;161:332-344. [PubMed: 2982989]

7. Francischetti IM, Valenzuela JG, Andersen JF, Mather TN, Ribeiro JMC. Ixolaris, a novel recombinant tissue factor pathway inhibitor (TFPI) from the salivary gland of the tick, Ixodes scapularis: identification of factor $\mathrm{X}$ and factor $\mathrm{Xa}$ as scaffolds for the inhibition of factor VIIa/tissue factor complex. Blood 99:3602-3612. [PubMed: 11986214]

8. Tatchell RJ. A modified method for obtaining tick oral secretion. J Parasitol 1967;53:1106-1107. [PubMed: 6062065]

9. Zhang JC, Claffey C, Sakthivel R, Darzynkiewicz Z, Shaw DE, Leal J, Wang YC, Lu FM, McCrae KR. Two-chain high molecular weight kininogen induces endothelial cell apoptosis and inhibits angiogenesis: partial activity within domain 5. FASEB J 2000;14:2589-2600. [PubMed: 11099478]

10. Mosnier LO, Griffin JH. Inhibition of staurosporine-induced apoptosis of endothelial cells by activated protein $\mathrm{C}$ requires protease-activated receptor-1 and endothelial cell protein $\mathrm{C}$ receptor. Biochem J 2003;373:65-70. [PubMed: 12683950]

11. Guo YL, Wang S, Colman RW. Kininostatin, an angiogenic inhibitor, inhibits proliferation and induces apoptosis of human endothelial cells. Arterioscler Thromb Vasc Biol 2001;21:1427-1433. [PubMed: 11557667] 
12. Malinda KM, Nomizu M, Chung M, Delgado M, Kuratomi Y, Yamada Y, Kleinman HK, Ponce ML. Identification of laminin $\alpha 1$ and $\beta 1$ chain peptides active for endothelial cell adhesion, tube formation, and aortic sprouting. FASEB J 1999;13:53-62. [PubMed: 9872929]

13. Ponce ML, Nomizu M, Kleinman HK. An angiogenic laminin site and its antagonist bind through the $\alpha(v) \beta 3$ and $\alpha 5 \beta 1$ integrins. FASEB J 2001;15:1389-1397. [PubMed: 11387236]

14. Ribeiro JM, Zeidner NS, Ledin K, Dolan MC, Mather TN. How much pilocarpine contaminates pilocarpine-induced tick saliva? Med Vet Entomol 2004;18:20-24. [PubMed: 15009442]

15. Lee Y, Schacter E. Oxidative stress inhibits apoptosis in human lymphoma cells. J Biol Chem 1999;274:19792-19798. [PubMed: 10391922]

16. Stupack DG, Cheresh DA. Apoptotic cues from the extracellular matrix: regulators of angiogenesis. Oncogene 2003;22:9022-9029. [PubMed: 14663480]

17. You WK, Seo HJ, Chung KH, Kim DS. A novel metalloprotease from Gloydius halys venom induces endothelial cell apoptosis through its protease and disintegrin-like domains. J Biochem 2003;134:739-749. [PubMed: 14688240]

18. Francischetti IM, Mather TN, Ribeiro JM. Penthalaris, a novel recombinant five-Kunitz tissue factor pathway inhibitor (TFPI) from the salivary gland of the tick vector of Lyme disease, Ixodes scapularis. Thromb. Haemost 2004;91:886-898.

19. Narasimhan S, Koski RA, Beaulieu B, Anderson JF, Ramamoorthi N, Kantor F, Cappello M, Fikrig E. A novel family of anticoagulants from the saliva of Ixodes scapularis. Insect Mol Biol 2002;11:641-650. [PubMed: 12421422]

20. Valenzuela JG, Charlab R, Mather TN, Ribeiro JM. Purification, cloning, and expression of a novel salivary anticomplement protein from the tick, Ixodes scapularis. J. Biol. Chem 2000;275:1871718723.

21. Montgomery RR, Lusitani D, De Boisfleury Chevance A, Malawista SE. Tick saliva reduces adherence and area of human neutrophils. Infect Immun 2004;72:2989-2994. [PubMed: 15102811]

22. Valenzuela JG, Francischetti IM, Pham VM, Garfield MK, Mather TN, Ribeiro JM. Exploring the sialome of the tick Ixodes scapularis. J. Exp. Biol 2002;18:2843-2864.

23. Francischetti IM, Mather TN, Ribeiro JM. Cloning of a salivary gland metalloprotease and characterization of gelatinase and fibrin(ogen)lytic activities in the saliva of the Lyme disease tick vector Ixodes scapularis. Biochem Biophys Res Commun 2003;305:869-875. [PubMed: 12767911]

24. Bjarnason JB, Fox JW. Snake venom metalloendopeptidases: reprolysins. Methods Enzymol 1995;248:345-368. [PubMed: 7674931]

25. Brassard DL, Maxwell E, Malkowski M, Nagabhushan TL, Kumar CC, Armstrong L. Integrin alpha (v)beta(3)-mediated activation of apoptosis. Exp Cell Res 1999;251:33-45. [PubMed: 10438569]

26. Cominetti MR, Ribeiro JU, Fox JW, Selistre deAraujo HS. BaG, a new dimeric metalloproteinase/ disintegrin from the Bothrops alternatus snake venom that interacts with $\alpha 5 \beta 1$ integrin. Arch. Biochem. Biophys 2003;416:171-179.

27. Francischetti IM, My-Pham V, Harrison J, Garfield MK, Ribeiro JM. Bitis gabonica (Gaboon viper) snake venom gland: toward a catalog for the full-length transcripts (cDNA) and proteins. Gene 2004;337:55-69. [PubMed: 15276202]

28. Wu WB, Huang TF. Activation of MMP-2, cleavage of matrix proteins, and adherens junctions during a snake venom metalloproteinase-induced endothelial cell apoptosis. Exp Cell Res 2003;288:143157. [PubMed: 12878166]

29. Zhang Z, Vuori K, Reed JC, Ruoslahti E. The $\alpha 5 \beta 1$ integrin supports survival of cells on fibronectin and up-regulates Bcl-2 expression. Proc Natl Acad Sci USA 1995;92:6161-6165. [PubMed: 7541142]

30. Takagi J, Strokovich K, Springer TA, Walz T. Structure of integrin $\alpha 5 \beta 1$ in complex with fibronectin. EMBO J 2003;22:4607-4615. [PubMed: 12970173]

31. Kim S, Bell K, Mousa SA, Varner JA. Regulation of angiogenesis in vivo by ligation of integrin $\alpha 5 \beta 1$ with the central cell-binding domain of fibronectin. Am J Pathol 2000;156:1345-1362. [PubMed: 10751360]

32. Pickering JG, Chow LH, Li S, Rogers KA, Rocnik EF, Zhong R, Chan BM. $\alpha 5 \beta 1$ integrin expression and luminal edge fibronectin matrix assembly by smooth muscle cells after arterial injury. Am $\mathrm{J}$ Pathol 2000;156:453-465. [PubMed: 10666375] 
33. Ingber DE. Fibronectin controls capillary endothelial cell growth by modulating cell shape. Proc Natl Acad Sci USA 1990;87:3579-3583. [PubMed: 2333303]

34. Molossi S, Elices M, Arrhenius T, Rabinovitch M. Lymphocyte transendothelial migration toward smooth muscle cells in interleukin-1 $\beta$-stimulated co-cultures is related to fibronectin interactions with $\alpha 4 \beta 1$ and $\alpha 5 \beta 1$ integrins. J Cell Physiol 1995;164:620-633. [PubMed: 7650068]

35. Zamir E, Katz M, Posen Y, Erez N, Yamada KM, Katz BZ, Lin S, Lin DC, Bershadsky A, Kam Z, Geiger B. Dynamics and segregation of cell-matrix adhesions in cultured fibroblasts. Nat Cell Biol 2000;2:191-196. [PubMed: 10783236]

36. Tarui T, Andronicos N, Czekay RP, Mazar AP, Bdeir K, Parry GC, Kuo A, Loskutoff DJ, Cines DB, Takada Y. Critical role of integrin $\alpha 5 \beta 1$ in urokinase (uPA)/urokinase receptor (uPAR, CD87) signaling. J Biol Chem 2003;278:29863-29872. [PubMed: 12754207]

37. Kloss CU, Werner A, Klein MA, Shen J, Menuz K, Probst JC, Kreutzberg GW, Raivich GJ. Integrin family of cell adhesion molecules in the injured brain: regulation and cellular localization in the normal and regenerating mouse facial motor nucleus. Comp Neurol 1999;411:162-178.

38. Feng X, Clark RA, Galanakis D, Tonnesen MG. Fibrin and collagen differentially regulate human dermal microvascular endothelial cell integrins: stabilization of alphav/beta3 mRNA by fibrin1. J Invest Dermatol 1999;113:913-919. [PubMed: 10594730]

39. Clark RAF, DellaPelle P, Manseua E, Lanigan JM, Dvorak HF, Colvin RB. Blood vessel fibronectin increases in conjunction with endothelial cell proliferation and capillary ingrowth during wound healing. J Invest Dermatol 1982;79:269-276. [PubMed: 6752289]

40. Engbring JA, Kleinman HK. The basement membrane matrix in malignancy. J Pathol 2003;200:465470. [PubMed: 12845613]

41. Fernandez PM, Patierno SR, Rickles FR. Tissue factor and fibrin in tumor angiogenesis. Sem Thromb Hemost 2004;30:31-44.

42. Tonnesen MG, Feng X, Clark RA. Angiogenesis in wound healing. J Invest Dermatol Symp Proc 2000;5:40-66.

43. Calvete JJ, Jurgens M, Marcinkiewicz C, Romeros A, Schrader M, Niewiarowski S. Disulphide-bond pattern and molecular modeling of the dimeric disintegrin EMF-10, a potent and selective integrin a5 $\beta 1$ antagonist from Eristocophis macmahoni venom. Biochem J 2000;345:573-581. [PubMed: 10642516]

44. Hembrough TA, Ruiz JF, Swerdlow BM, Swartz GM, Hammers HJ, Zhang L, Plum SM, Williams MS, Strickland DK, Pribluda VS. Identification and characterization of a very low density lipoprotein receptor-binding peptide from tissue factor pathway inhibitor that has antitumor and antiangiogenic activity. Blood 2004;103:3374-3380. [PubMed: 14739228]

45. Pike SE, Yao L, Setsuda J, Jones KD, Cherney B, Appella E, Sakaguchi K, Nakhasi H, Atreya CD, Teruya-Feldstein J, Wirth P, Gupta G, Tosato G. Calreticulin and calreticulin fragments are endothelial cell inhibitors that suppress tumor growth. Blood 1999;94:2461-2468. [PubMed: 10498619]

46. Gillespie RD, Mbow ML, Titus RG. The immunomodulatory factors of bloodfeeding arthropod saliva. Parasite Immunol 2000;22:319-331. [PubMed: 10886716]

47. Schoeler GB, Wikel SK. Modulation of host immunity by haematophagous arthropods. Ann Trop Med Parasitol 2001;95:755-771. [PubMed: 11784430]

48. Coleman JL, Gebbia JA, Piesman J, Degen JL, Bugge TH, Benach JL. Plasminogen is required for efficient dissemination of B. burgdorferi in ticks and for enhancement of spirochetemia in mice. Cell 1997;89:1111-1119. [PubMed: 9215633]

49. Zeidner NS, Schneider BC, Nuncio MS, Gern L, Piesman J. Coinoculation of borrelia spp. with tick salivary gland lysate enhances spirochete load in mice and is tick species-specific. J Parasitol 2002;88:1276-1278. [PubMed: 12537131]

50. Clark, RA. Physiology, biochemistry and molecular biology of the skin. 2. Goldsmith, LA., editor. Vol. I. Oxford University Press; New York, NY: 1991. p. 577 

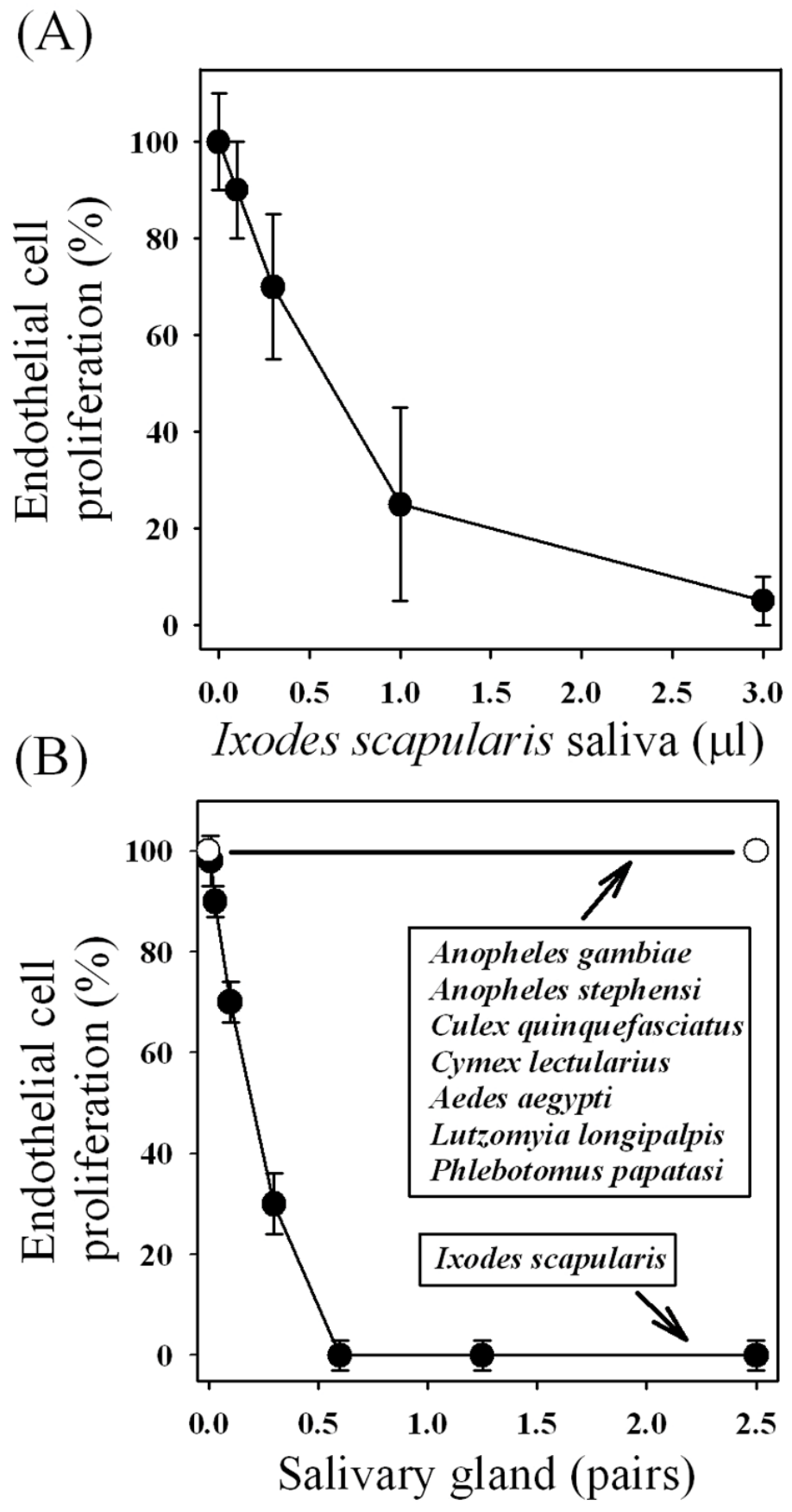

FIG. 1.

I. scapularis saliva and salivary gland inhibit microvascular endothelial cell (MVEC) proliferation: comparison with the salivary gland from other blood-sucking arthropods. MVEC were cultured in the presence of EBM-2 Plus for $24 \mathrm{~h}$ at $37^{\circ} \mathrm{C}$. The relative numbers of cells in each well and the percent inhibition of proliferation were determined using MTS solution. (A) I. scapularis saliva was added as indicated. (B) I. scapularis or other blood-sucking salivary glands were added as indicated. No inhibition was observed with An. gambiae, An. stephensi, Culex quinquefasciatus, Cimex lectularius, Aedes aegypti, Lutzomyia longipalpis, or Phlebotomus papatasi salivary glands (up to 2.5 pairs/assays; $n=8$ ). Partial inhibition was observed with 1 pair/assay of Rhodnius prolixus salivary gland, and total inhibition was 
detected with $\sim 1$ pair/assay of Boophilus microplus salivary gland (not shown; $\mathrm{n}=3$ ). Similar results were obtained with human umbilical vein endothelial cells (HUVEC) for all salivary glands tested (not shown; $\mathrm{n}=5$ ). 

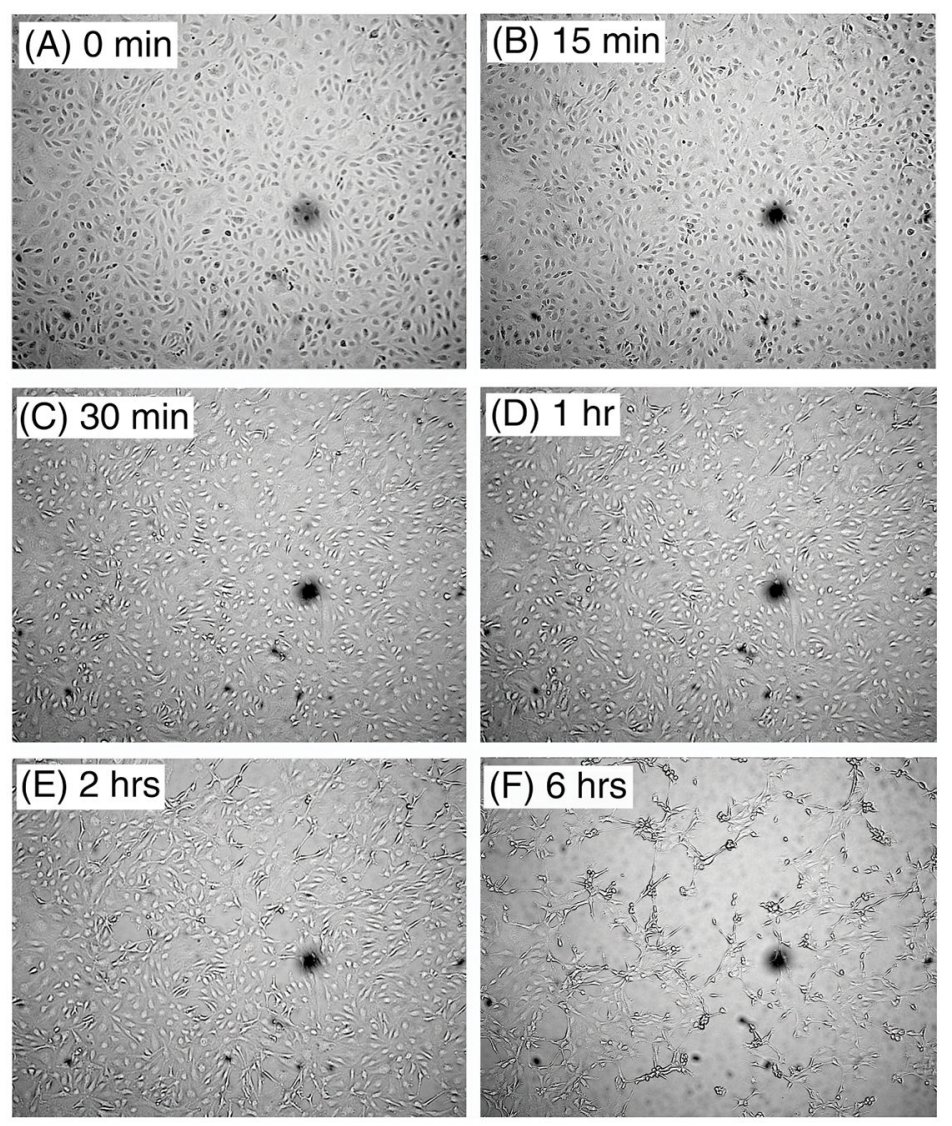

FIG. 2.

Tick saliva induces a rapid change in the morphology of MVEC. Tick saliva was added to $80 \%$ to $90 \%$ confluent MVEC and pictures taken at the indicated time points. (A) Control (buffer, $6 \mathrm{~h}$ ); (B) saliva (15 min); (C) saliva (30 min); (D) saliva (1 h); (E) saliva (2 h) and (F) saliva (6 h). Magnification: $50 \times(\mathrm{n}=10)$. 


\section{(A) Buffer}
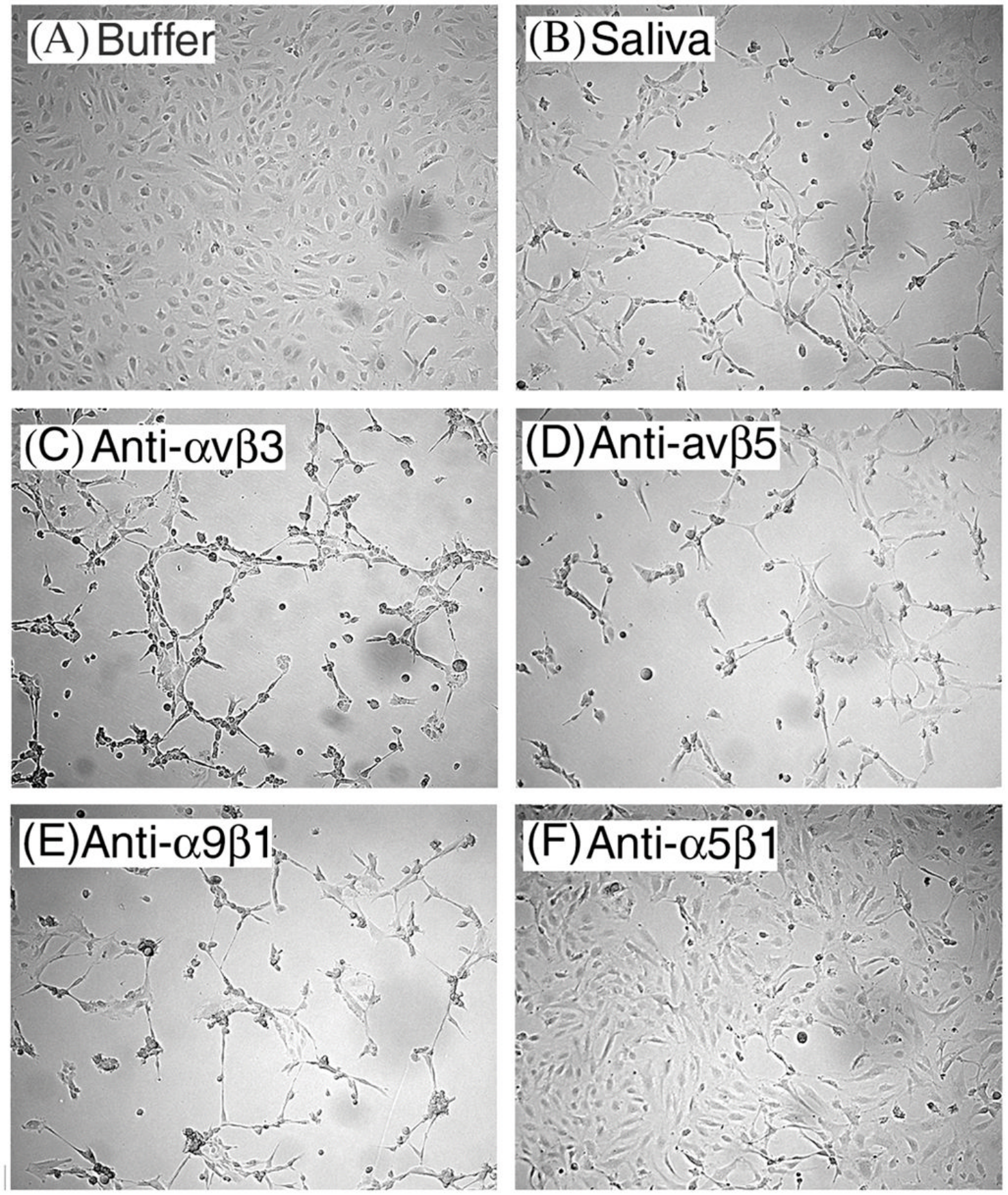

FIG. 3.

Treatment of endothelial cells with anti-integrin antibody prevents change on MVEC caused by tick saliva. Tick saliva was added to $80 \%$ to $90 \%$ confluent MEVC previously incubated for $1 \mathrm{~h}$ with purified $\mathrm{mAb}(25 \mu \mathrm{g} / \mathrm{ml})$ when indicated: (A) buffer, no saliva; (B) saliva (5 $\mu \mathrm{l})$; (C) anti- $\alpha \beta \beta 3$ (LM609); (D) anti- $\alpha v \beta 5$ (P1F6); (E) anti- $\alpha 9 \beta 1$ (Y9A2); and (F) anti- $\alpha 5 \beta 1$ (HA6). Similar results were observed with anti- $\alpha \mathrm{v} \beta 3$ (23C6), anti- $\alpha \mathrm{v} \beta 5$ (P1F76) mAbs that did not attenuate the effects of saliva, whereas inhibition was observed with ascites anti- $\alpha 5 \beta 1$ (JBS4) $\mathrm{mAb}$ (pictures not shown). Pictures were taken after $6 \mathrm{hr}$ of incubation with saliva $(\mathrm{n}=3)$. Magnification: $80 \times$. No effects were observed when the following mAb were used: anti- $\alpha 1$, - 
$\alpha 2,-\alpha 3,-\alpha 4,-\alpha 5,-\alpha 6,-\beta 1,-\beta 2,-\alpha v,-\alpha 2 \beta 1$, or $-\alpha 3 \beta 1(n=3)$. mAbs alone did not affect the MVEC shape. 


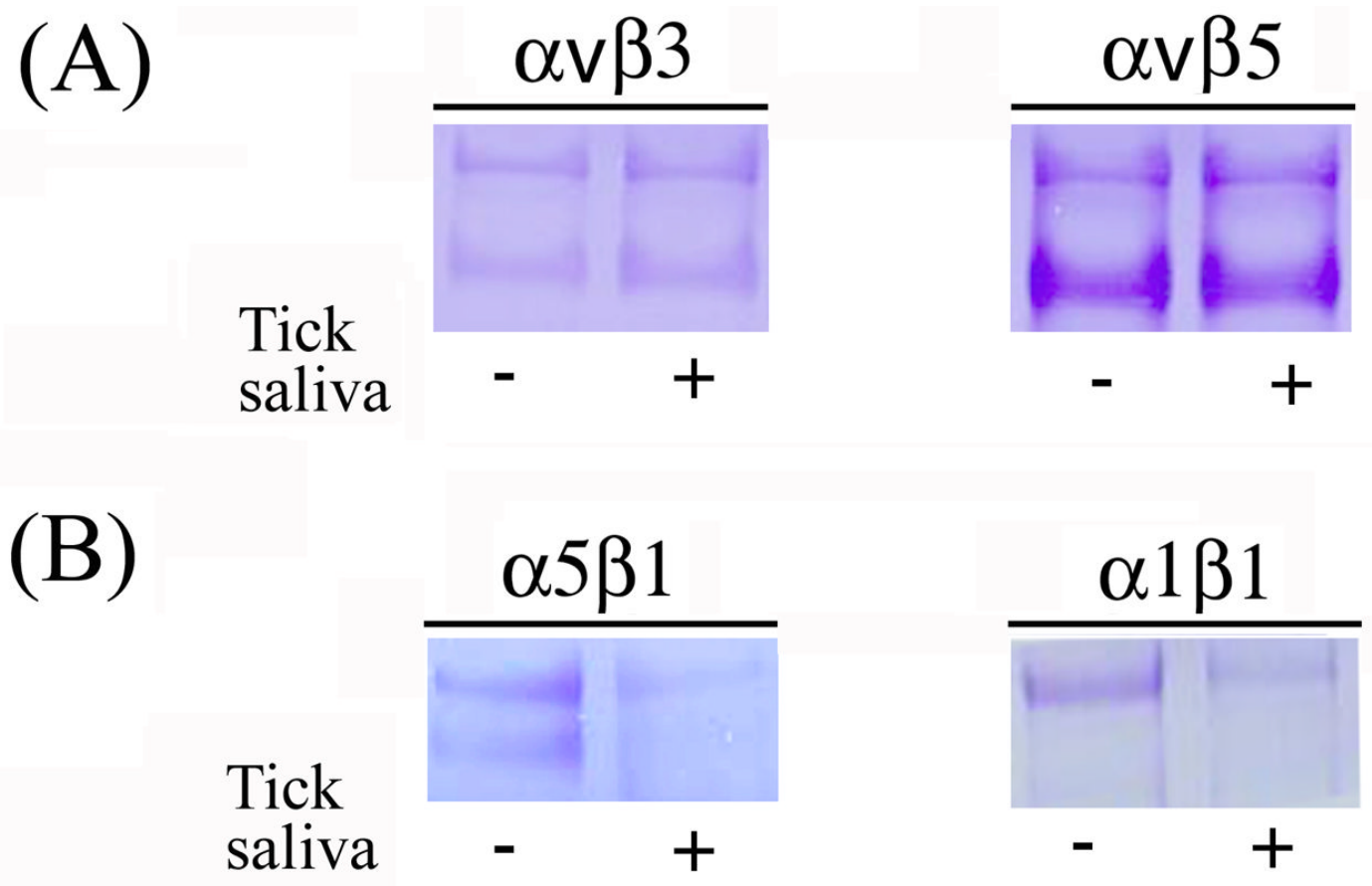

(C)

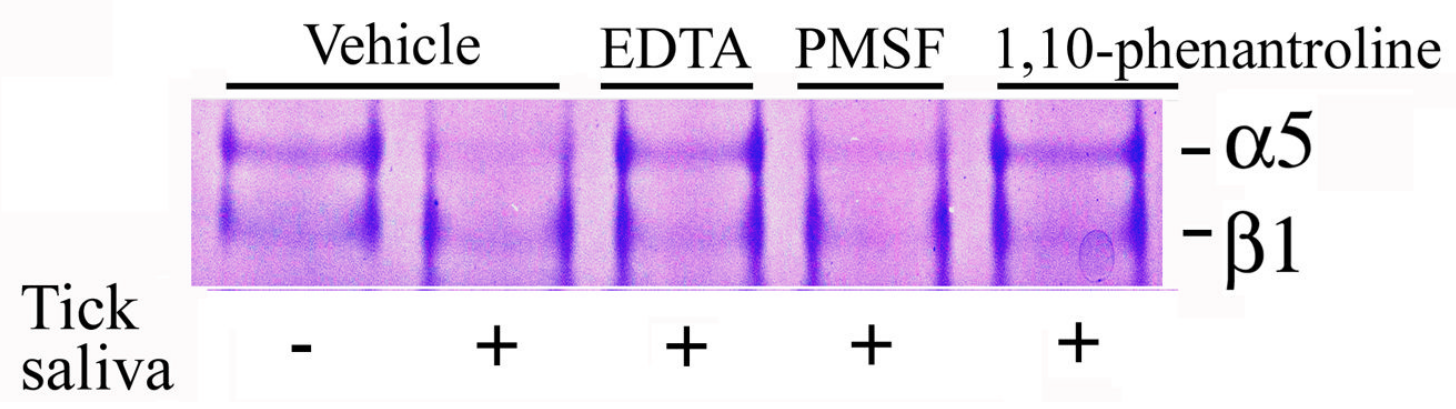

FIG. 4.

Saliva degrades purified integrin $\alpha 5 \beta 1$ and $\alpha 1 \beta 1$, but not $\alpha v \beta 3$ or $\alpha v \beta 5$ : Effects of inhibitors. In (A) purified integrins $\alpha v \beta 3$ or $\alpha v \beta 5$ were incubated with saliva overnight at $37^{\circ} \mathrm{C}$ in EBM-2 and no degradation was observed after SDS/PAGE and staining with $0.2 \%$ Coomassie blue (n $=5)$. In (B) purified integrins $\alpha 5 \beta 1$ and $\alpha 1 \beta 1$ were incubated with saliva as in (A) and degradation was observed for both $\alpha$ and $\beta$ chains after SDS/PAGE and staining as above. (C) The metalloprotease inhibitors EDTA $(20 \mathrm{mM})$ or 1,10 -phenanthroline $(2.5 \mathrm{mM})$, and the serine protease inhibitor PMSF $(2.5 \mathrm{mM})$ were incubated for 30-min with saliva followed by addition of integrin $\alpha 5 \beta 1$ and overnight incubation as in (A) followed by SDS/PAGE and staining as above. The gel shows that degradation of $\alpha 5 \beta 1$ did not occur when saliva was treated with EDTA or 1,10-phenanthroline, but was observed in the presence of PMSF (n=4). Results are from a typical experiment. 

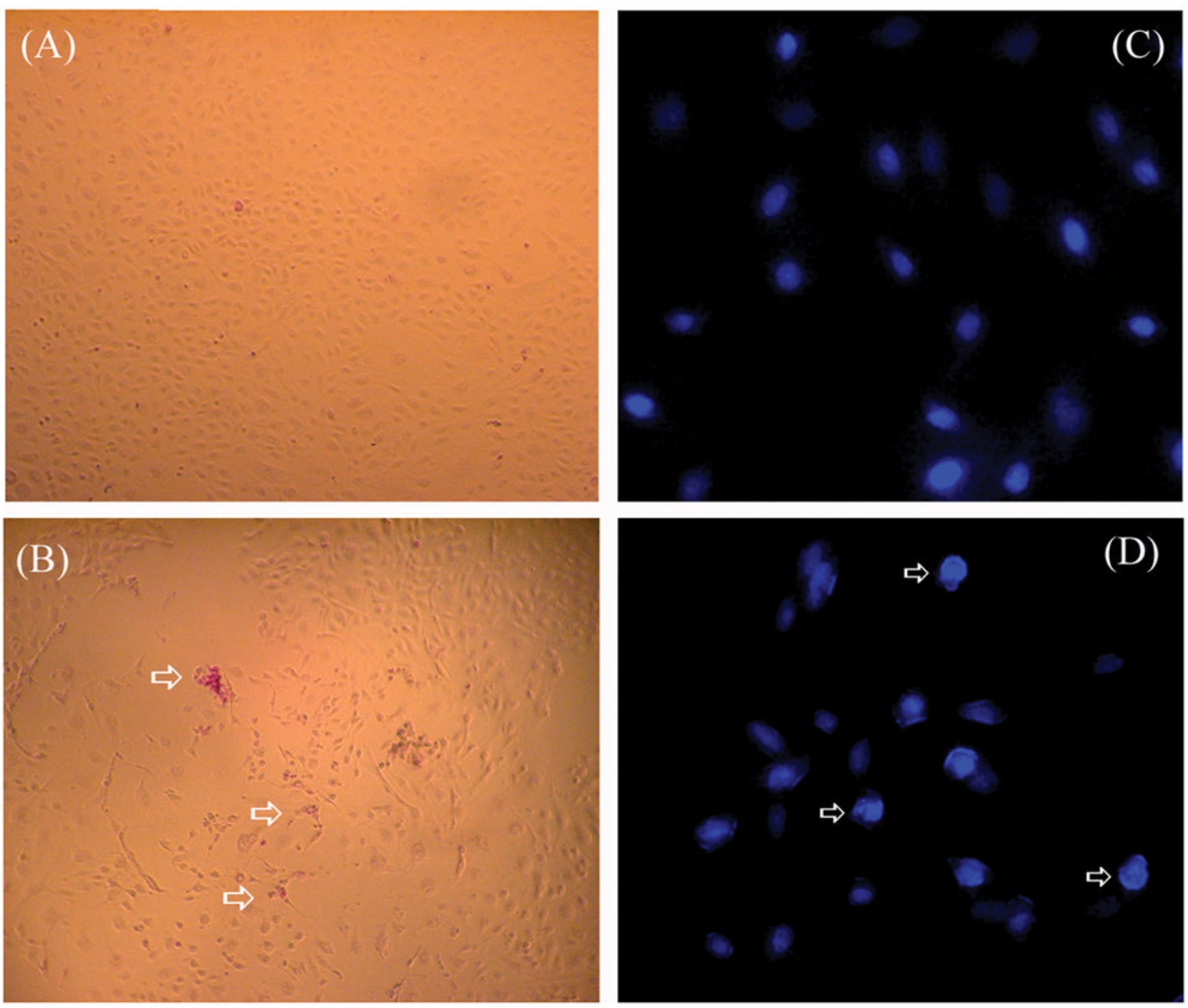

FIG. 5.

Tick saliva induces apoptosis in endothelial cells. (A) MVEC were incubated in the absence or (B) presence of saliva for 4 hours and stained with Apopercentage dye (see Methods). In (A) cells are not stained confirming its viability and non-apoptotic nature, whereas in (B) arrows indicate the red-purple stained cells indicate apoptosis. Magnification: 50x $(n=3)$. (C) MVEC were incubated in the absence or (D) presence of saliva for 6 hours and stained with Hoechst 33258 (see Methods). In (C), nuclear contour is regular and smooth, whereas in (D), arrows indicate cells with irregular nuclear contour, with nuclear hyperchromaticity, chromatin condensation, and fragmentation typical of apoptosis. Magnification: $200 \times(n=3)$. 

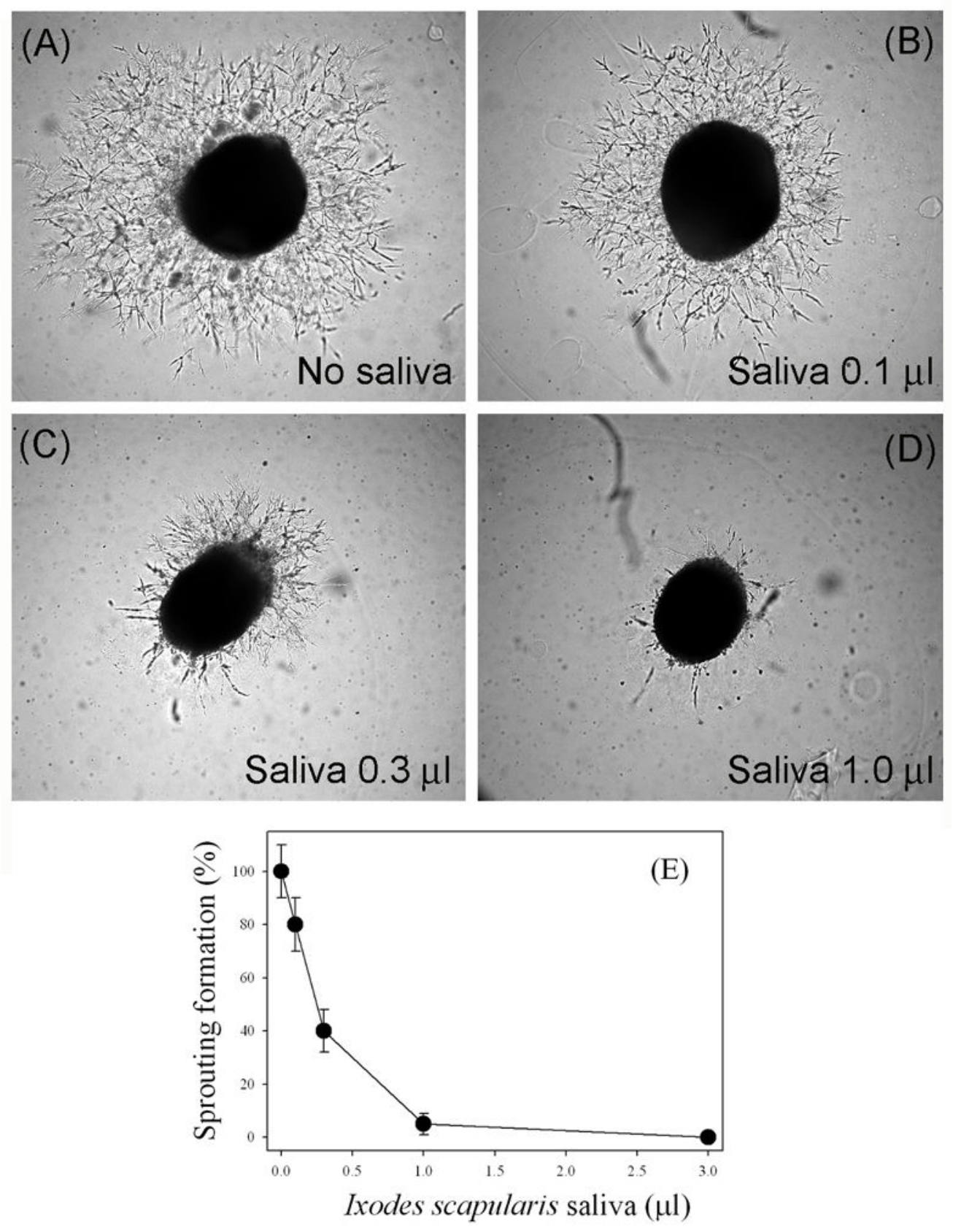

FIG. 6.

Tick saliva inhibits sprouting formation from 12-day-old chick embryo aorta. Saliva was added to chick embryo aorta as described. After 3 days of incubation at $37^{\circ} \mathrm{C}, 5 \% \mathrm{CO}_{2}$, pictures were taken. (A) No saliva. (B) Saliva $(0.1 \mu \mathrm{l})$. (C) Saliva $(0.3 \mu \mathrm{l})$. (D) Saliva (1 $\mu \mathrm{l})$. (E) Dose-response curve for the inhibition of sprouting formation by saliva $(n=8)$. Magnification: $50 x$. 


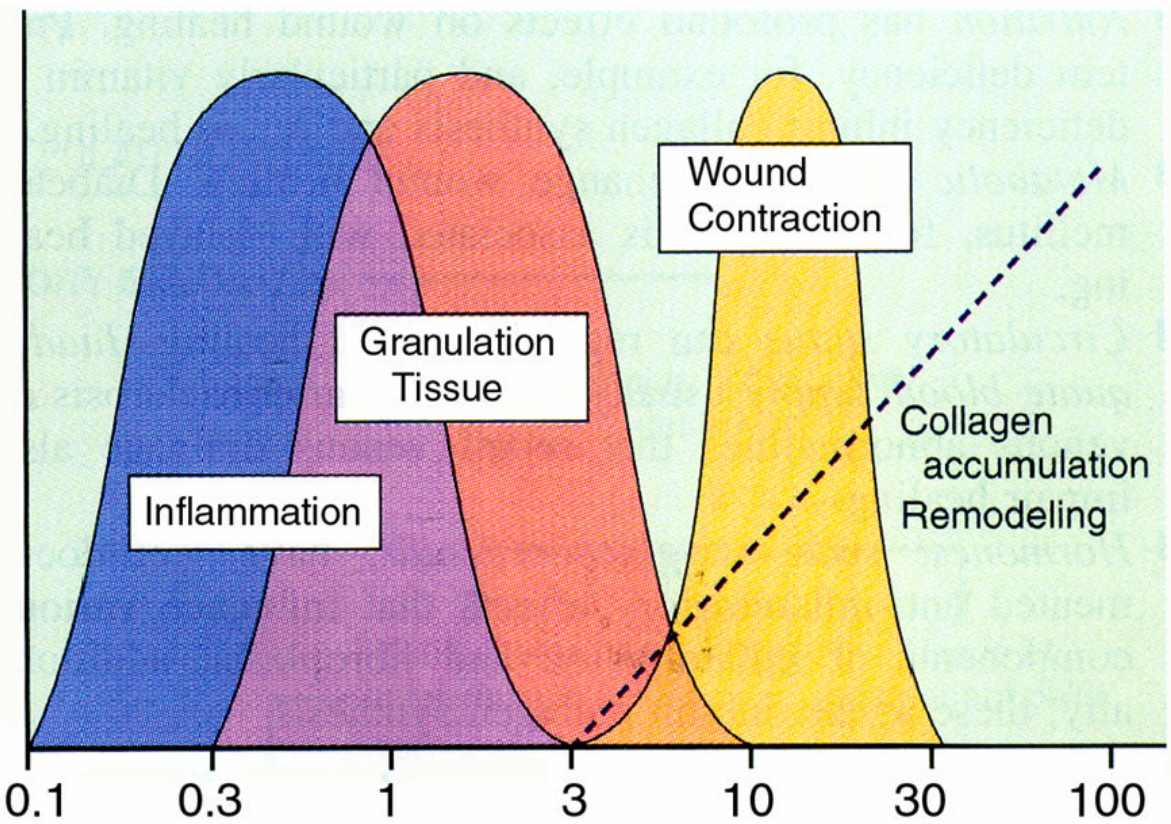

Days after injury

Ixolaris

Penthalaris ISAC

SALP 14

Kininase

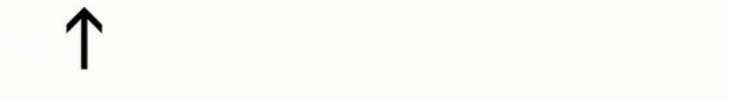

Salivary angiogenesis inhibitor(s) (e.g.: metalloprotease ?) Neutrophil inhibitor

FIG. 7.

Orderly phases of wound healing and the effects of salivary components. Wound healing is divided in three phases: inflammatory (inflammation), proliferative (granulation tissue), and remodeling (wound contraction) phases. Salivary molecules Ixolaris (7), Penthalaris (18), SALP14 (19), ISAC (20), a salivary inhibitor of neutrophil function $(6,21)$, and a bradykinindegrading kininase (22) — work in concert to effectively block the acute phase of inflammation. Later stages of inflammation, during which endothelial cell-dependent granulation tissue formation takes place, appear to be counteracted by tick salivary components displaying antiangiogenesis activities. Modified from R. A. Clark, 1991 (50). 